\title{
Sexually-transmitted diseases in women
}

\author{
JOHAN WALLIN, HAKAN GNARPE, AND ARNE FORSGREN \\ From the Department of Dermatology and Venereology, University Hospital, Uppsala, and the Institute of \\ Medical Microbiology, University of Uppsala, Uppsala, Sweden
}

Most acute or recurrent genital infections are caused by micro-organisms other than $N$. gonorrhoeae (Willcox, 1972). Recently, the possible significance of mycoplasmas in genital infections has especially been studied. $M$. hominis is commonly isolated from patients with cervicitis, vaginitis, or pelvic inflammatory disease (McCormack, Braun, Lee, Klein, and Kass, 1973). Two cases of T-mycoplasmaemia have been reported in pregnant women (Sompolinsky, Solomon, Leiba, Caspi, Lewinsohn, and Almog, 1971; Caspi, Herczeg, Solomon, and Sompolinsky, 1971), and it has been suggested that $\mathrm{T}$-mycoplasmas may be responsible for some cases of spontaneous abortion (Caspi, Solomon, and Sompolinsky, 1972).

Group B streptococci in the vagina during pregnancy are considered to be a potential source of neonatal sepsis (Franciosi, Knostman, and Zimmerman, 1973). Trichomonas vaginalis and Candida albicans are generally regarded as vaginal pathogens, as is also Corynebacterium vaginale (Haemophilus vaginalis) (Gardner and Dukes, 1955). Vulvitis and vaginitis are frequently associated with Trichomonas and Candida but not with $C$. vaginale (Robinson and Mirchandani, 1965). Candida is said to be influenced by the female menstrual and pregnancy cycles (Drake and Maibach, 1973).

We here describe a study planned to evaluate the relationship between the cervical microbiology and the presence of symptoms or signs of venereal disease in a series of consecutive patients at the time of their first visit to the clinic.

\section{Material and methods}

\section{PATIENTS}

All new female patients attending the Venereal Disease Clinic of the University Hospital in Uppsala between February and May, 1972, were included in this study. Excepted were patients who had taken antibiotics during

Received for publication October 2,1973 a 2-week period before their first visit and patients already treated elsewhere who were seen only for follow-up.

The final series comprised 341 women ranging in age from 14 to 40 years (mean 22).

\section{METHODS}

A careful history was taken from each patient. The data were coded for computer analysis, as were those obtained by clinical examination and microbiological cultures. 54 per cent. of the patients were examined by Dr. Wallin and the remainder by other venereologists working at the clinic.

\section{CLINICAL PROCEDURE}

Four specimens were taken from the cervical canal with charcoal-coated cotton-wool swabs and placed in separate tubes of transport medium:

(1) For bacteria, trypticase soy broth (Difco) partly stabilized with 3 per cent. sucrose ;

(2) For 'classical' mycoplasmas, mycoplasma broth (Chanock, Hayflick, and Barile, 1962);

(3) For T-mycoplasmas, Shepard's U9 broth (Shepard and Lunceford, 1970);

(4) For protozoa and yeasts, Diamond's medium (Diamond, 1957).

Slides were made from the first specimen and stained with methylene blue for direct microscopical examination for polymorphonuclear leucocytes. Ten or more polymorphonuclear leucocytes per high-power field (HPF) seen in several fields using a $\times 100$ objective and $\times 12.5$ eyepiece were recorded as a leucocytic reaction; fewer than ten WBC/HPF were recorded as no reaction.

Fresh smears of vaginal discharge in saline were examined for $T$. vaginalis within 5 minutes after collection, as recommended by Eddie (1968).

The criteria used for classification of the patients were whether they complained of vaginal discharge and the number of leucocytes detected by direct microscopical examination of smears from the cervix. A vaginal discharge of more than 1 year's duration and which was considered normal by the patient was not recorded.

\section{MICROBIOLOGICAL PROCEDURE}

The time taken for transportation of the specimens to the laboratory never exceeded $5 \mathrm{hrs}$. On arrival at the 
laboratory, material from the swabs was inoculated onto conventional and protective media for the isolation of $N$. gonorrhoeae and L-phase organisms as described earlier (Gnarpe, Wallin, and Forsgren, 1972). Standard laboratory media (blood agar base plates-Difco, sodium-azide agar-Difco, haematin agar plates and CLED agar plates-Baltimore Biological Laboratory) were also inoculated for determination of the bacterial flora. All plates were incubated at $37^{\circ} \mathrm{C}$. for $48 \mathrm{hrs}$. The different bacterial species were indentified by means of standard laboratory techniques.

The swabs taken for mycoplasma isolation were transferred to fresh mycoplasma broth (Chanock, Hayflick and Barile, 1962) and to fresh U9 broth (Shepard and Lunceford, 1970). The conditions of cultivation were essentially those previously described (Gnarpe and Friberg, 1972).

'Classical' mycoplasmas were typed according to Clyde (1964) or, if they were not $M$. hominis, according to Aluotto, Wittler, Williams, and Faber (1970). T-mycoplasmas were identified by their capacity to split urea, their typical colonial morphology, and their sensitivity to erythromycin.

Trichomonas vaginalis was cultivated as described earlier (Wallin and Forsgren, 1974). Subcultures were also made from Trichomonas media onto Saboraud's medium (Difco) for isolation of yeasts. Candida albicans was distinguished from other yeasts by the use of Dubos' medium, but no further typing was done.

\section{Results}

The frequencies of different micro-organisms in cultures from cervical specimens are shown in Table I.

TABLE I Microbiological findings in cervical specimens from 341 women

\begin{tabular}{|c|c|c|}
\hline Organisms & Type & Percentage \\
\hline Bacteria & $\begin{array}{l}\text { Staph. aureus } \\
\text { Staph. albus } \\
\text { Streptococci } \\
\text { Enterococci } \\
\text { N. gonorrhoeae } \\
\text { C. vaginale } \\
\text { L-forms }\end{array}$ & $\begin{array}{r}3 \\
44 \\
11 \\
10 \\
20 \\
3 \\
13\end{array}$ \\
\hline Mycoplasmas & $\begin{array}{l}\text { M. hominis } \\
\text { T-mycoplasmas }\end{array}$ & $\begin{array}{l}32 \\
53\end{array}$ \\
\hline Yeasts & $\begin{array}{l}\text { C. albicans } \\
\text { Others }\end{array}$ & $\begin{array}{r}28 \\
6\end{array}$ \\
\hline Protozoa & T. vaginalis & 12 \\
\hline
\end{tabular}

In Tables II to $\mathrm{V}$, the occurrence of the most common micro-organisms has been correlated with various criteria. Staphylococcus albus and the organisms occurring in low frequency shown in Table I are not included here, but they were evenly distributed among the various groups.
The correlation between culture results and the leucocytic reaction seen on direct microscopical examination of the smears is shown in Table II.

TABLE II Percentage of positive findings in cervical specimens from women with and without leucocytic reaction in the cervical smear

\begin{tabular}{lll}
\hline $\begin{array}{l}\text { Type of } \\
\text { culture }\end{array}$ & \multicolumn{2}{l}{ Percentage of positive cultures } \\
\cline { 2 - 3 } & $\begin{array}{l}97 \text { women with } \\
\text { leucocytic reaction }\end{array}$ & $\begin{array}{c}244 \text { women without } \\
\text { leucocytic reaction }\end{array}$ \\
\cline { 2 - 3 }$N$. gonorrhoeae & $36^{\mathrm{a}}$ & 13 \\
$M$. hominis & 27 & $35^{\mathrm{a}}$ \\
$\mathrm{T}$-mycoplasmas & 61 & 51 \\
$C$. albicans & 25 & 29 \\
$T$. vaginalis & $20^{\mathrm{b}}$ & 9 \\
\hline ap $<0.001$ & & \\
bP $<0.01$ & &
\end{tabular}

36 per cent. of the women with a leucocytic reaction in the cervical smear had positive cultures for $N$. gonorrhoeae, compared with 13 per cent. of the women without a leucocytic reaction $(P<0.001)$; $T$. vaginalis was also more common among those with a leucocytic reaction $(P<0.01)$; the corresponding figures were 20 and 9 per cent. respectively.

The micro-organisms isolated from 67 women with a gonococcal infection are shown in Table III, in which the patients are divided into groups according to leucocytic reaction in the cervical smear and symptoms. A leucocytic reaction was found in 35 women ( 52 per cent.), and forty women ( 60 per cent.) complained of vaginal discharge. 40 per cent. of the patients with a leucocytic reaction had positive cultures for $M$. hominis and 20 per cent. for $T$. vaginalis. The corresponding figures for those without a leucocytic reaction were 25 and 6 per cent. respectively. These differences, however, are not significant. The percentages of positive cultures for all non-gonococcal micro-organisms were about the same among women with and without symptoms.

TABLE III Findings in cervical specimens from 67 women with gonococcal infection. Patients grouped according to leucocytic reaction and symptoms

\begin{tabular}{|c|c|c|c|c|}
\hline $\begin{array}{l}\text { Type of } \\
\text { culture }\end{array}$ & $\begin{array}{l}\text { Leucocytic } \\
\text { reaction } \\
\text { (per cent.) }\end{array}$ & $\begin{array}{l}\text { No } \\
\text { leucocytic } \\
\text { reaction } \\
\text { (per cent.) }\end{array}$ & $\begin{array}{l}\text { Vaginal } \\
\text { discharge } \\
\text { (per cent.) }\end{array}$ & $\begin{array}{l}\text { No } \\
\text { vaginal } \\
\text { discharge } \\
\text { (percent.) }\end{array}$ \\
\hline $\begin{array}{l}\text { M. hominis } \\
\text { T-mycoplasmas } \\
C . \text { albicans } \\
T \text {. vaginalis }\end{array}$ & $\begin{array}{l}40 \\
66 \\
20 \\
20\end{array}$ & $\begin{array}{r}25 \\
69 \\
19 \\
6\end{array}$ & $\begin{array}{l}30 \\
72 \\
18 \\
13\end{array}$ & $\begin{array}{l}37 \\
63 \\
22 \\
15\end{array}$ \\
\hline $\begin{array}{l}\text { Total number } \\
\text { of patients }\end{array}$ & 35 & 32 & 40 & 27 \\
\hline
\end{tabular}


In Table IV, the culture findings from cervical specimens of women with $N$. gonorrhoeae, $T$. vaginalis, and $M$. hominis are compared with the findings from a control group of patients without gonorrhoea and without signs of venereal disease, i.e. no discharge and no leucocytic reaction in the smear. The control group had fewer $\mathrm{T}$-mycoplasmas $(P<0.01)$ than the other groups. Unspecified L-phase organisms were found in 28 per cent. of the women with a growth of $T$. vaginalis, a significant difference from the 6 per cent. found in the control group $(P<0.001)$.

Positive cultures for $C$. albicans were found to increase in frequency during the later phases of the menstrual cycle, as demonstrated in Table V. In this Table the mid-cycle represents a period of 2 weeks and the other parts of the cycle 1 week each.

Contraceptive pills were used by 54 per cent. of the women and there were no microbiological differences between users and non-users.

TABLE V Microbiological findings in specimens from 341 women correlated with phases of the menstrual cycle

\begin{tabular}{|c|c|c|c|c|c|}
\hline \multirow[t]{2}{*}{ Type of culture } & \multicolumn{5}{|c|}{ Days of the menstrual cycle (per cent.) } \\
\hline & $0-7$ & $8-21$ & $22-30$ & $>30$ & Total \\
\hline N. gonorrhoeae & 19 & 51 & 21 & 9 & 100 \\
\hline L-forms & 20 & 68 & 9 & 3 & 100 \\
\hline M. hominis & 17 & 55 & 20 & 8 & 100 \\
\hline T-mycoplasmas & 18 & 51 & 23 & 8 & 100 \\
\hline C. albicans & 11 & 52 & 31 & 6 & 100 \\
\hline T. vaginalis & 18 & 55 & 20 & 7 & 100 \\
\hline $\begin{array}{l}\text { Total percentage } \\
\text { of patients }\end{array}$ & 17 & 54 & 23 & 6 & 100 \\
\hline
\end{tabular}

Table VI compares the results of direct microscopical examination of smears for $T$. vaginalis with the results of cultures. Among 42 women harbouring $T$. vaginalis, the parasite could be demonstrated in wet smears in 61 per cent. and culture was negative in only one case. Positive smears as well as cultures were found, however, in 86 per cent. of those women who had clinical symptoms of $T$. vaginalis infection.

TABLE VI Correlation of $\mathrm{T}$. vaginalis diagnosed by vaginal smear and by cervical culture in 42 women

\begin{tabular}{lllll}
\hline Culture & & Positive & Negative \\
\cline { 5 - 5 } \cline { 5 - 5 } Smear & & Positive & 25 & 1 \\
& Negative & 16 & - \\
\hline
\end{tabular}

Various methods of detecting $T$. vaginalis and transporting specimens to the laboratory were used from February to September, 1972. In 324 cases one charcoal-coated swab was taken from the cervical canal and another from the vaginal fornix and both were sent to the laboratory in Diamond's medium. Positive cultures were obtained from 45 and 44 respectively. During another period, 954 duplicate cervical swabs were taken and sent in Stuart's and Diamond's media. The time taken in transit did not exceed $5 \mathrm{hrs}$. Positive cultures resulted from 86 ( 9 per cent.) and 95 (10 per cent.) of these specimens respectively. Concomitant cultures for $N$. gonorrhoeae were inoculated from the swabs sent in Stuart's medium.

\section{Discussion}

Patients attending a clinic for venereal diseases present many different genital disorders, of which the 'non-specific' infections form the major part (Department of Health and Social Security, 1971). The results of this study indicate that most bacteria have no importance for the development of vaginal discharge or of a cervical reaction with an increased number of leucocytes.

TABLE IV Percentages of positive cultures from cervical specimens grouped according to microbiological criteria

\begin{tabular}{|c|c|c|c|c|}
\hline \multirow[t]{2}{*}{ Type of culture } & \multicolumn{3}{|l|}{ Positive cultures } & \multirow{2}{*}{$\begin{array}{l}\text { Negative N. gonorrhoeae } \\
\text { No discharge or } \\
\text { leucocytic reaction } \\
\text { (per cent.) }\end{array}$} \\
\hline & $\begin{array}{l}\text { N. gonorrhoeae } \\
\text { (per cent.) }\end{array}$ & $\begin{array}{l}\text { M. hominis } \\
\text { (per cent.) }\end{array}$ & $\begin{array}{l}\text { T. vaginalis } \\
\text { (per cent.) }\end{array}$ & \\
\hline $\begin{array}{l}\text { N. gonorrhoeae } \\
\text { L-forms } \\
\text { M. hominis } \\
\text { T-mycoplasmas } \\
\text { C. albicans } \\
T \text {. vaginalis }\end{array}$ & $\begin{array}{c}100 \\
9 \\
33 \\
67^{\mathrm{b}} \\
19 \\
13\end{array}$ & $\begin{array}{c}25 \\
15 \\
100 \\
69^{\mathrm{b}} \\
21 \\
17\end{array}$ & $\begin{array}{l}23 \\
28^{\mathrm{a}} \\
48 \\
73^{\mathrm{a}} \\
15 \\
100\end{array}$ & $\begin{array}{r}0 \\
6 \\
28 \\
45 \\
28 \\
6\end{array}$ \\
\hline Total no. of patients & 67 & 111 & 41 & 97 \\
\hline
\end{tabular}

aP $<0.001$ ) for groups with positive cultures compared with group negative

${ }^{n} \mathbf{P}<0.01$ for $N$. gonorrhoeae and without discharge or leucocytic reaction 
Streptococci were cultured from 11 per cent. of the women, but Group B was found in only two cases. Other investigators (Gardner and Dukes, 1955) have reported a higher incidence of $C$. vaginale than we found. This may be because we did not use a special medium for the cultivation of $C$. vaginale.

$M$. hominis was isolated from 32 per cent. of the patients. In a group of pregnant patients without symptoms, the corresponding figure was 13 per cent. (Gnarpe and Friberg, 1972; Gnarpe, 1973). The presence of $M$. hominis in cervical specimens, however, did not seem to be of importance for the development of symptoms, as it was isolated in similar numbers from women with and without symptoms and from women with and without a leucocytic reaction.

T-mycoplasmas were isolated from 67 per cent. of the patients with $N$. gonorrhoeae, compared with 45 per cent. of controls without signs of infection and 23 per cent. of pregnant women without symptoms (Gnarpe and Friberg, 1972). It is possible, however, that the relatively high frequency of $\mathrm{T}$-mycoplasmas in the gonorrhoea group merely reflects sexual activity, as has been reported in a study by McCormack, Almeida, Bailey, Grady, and Lee (1972). We found that 13 per cent. of our controls had not had intercourse during the last 30 days, compared with 4 per cent. in the gonorrhoea group. This difference, however, is not statistically significant.

The increasing incidence of gonorrhoea is now recognized as being largely due to asymptomatic infection (Pariser, 1972), and this type of gonorrhoea is also responsible for many of the cases with disseminated infection, especially among women (Holmes, Counts, and Beaty, 1971). We found no significant differences in the microbiological findings between patients with symptomatic and asymptomatic gonorrhoea or between patients with and without a leucocytic reaction. $N$. gonorrhoeae and $T$. vaginalis were the only organisms isolated significantly more often from women with a leucocytic reaction. This is in agreement with our earlier findings (Wallin, 1974), using the leucocytic reaction as an indication of gonorrhoea. Therefore, failure to isolate $N$. gonorrhoeae in cases with a leucocytic reaction is suggestive of a $T$. vaginalis infection. Growth of L-forms occurs with a high frequency in patients infected with $T$. vaginalis. The relevance of this finding is, for the moment, unknown.

Recent reports have suggested a causative relationship between oral contraceptives and vaginal candidosis (Catterall, 1971). In this investigation we could find no difference in the frequency of vaginal candidosis between users and non-users. This is probably due to the use of contraceptives with a low hormonal content. In most investigations in which Candida infection was positively correlated with the use of oral contraceptives, preparations with higher hormonal content were involved (Yaffee and Grots, 1965; Porter and Lyle, 1966; Catterall, 1966); the hormonal content has been shown to be of importance for the presence of Candida (Rohatiner and Grimble, 1970).

Trichomonas vaginalis was cultured from specimens from 41 women. An immediate diagnosis could be established by microscopical examination of unstained specimens in only 61 per cent. of these cases, which is in accordance with the findings of Bartunek and Schultze (1972). In symptomatic cases, however, $T$. vaginalis could be detected microscopically in 86 per cent. Because of the high frequency of Trichomonas infection in patients with a leucocytic reaction, culture for $T$. vaginalis is especially recommended for such patients in whom no organisms can be detected by direct microscopical examination of the wet smear. This investigation shows that specimens taken on charcoal-coated swabs and sent to the laboratory in Stuart's transport medium are as satisfactory for the culture of $T$. vaginalis as they were earlier demonstrated to be for $N$. gonorrhoeae (Gästrin and Kallings, 1968). Similar results were obtained when $T$. vaginalis was cultured from specimens taken at the same time from vagina and cervix and transported in Diamond's medium.

\section{Summary}

The cervical microbiology has been studied in 341 consecutive new patients attending a Venereal Disease Clinic. The results indicate that most bacteria have no influence on the development of vaginal discharge or on an increase in the number of leucocytes in the cervical secretion. Mycoplasmas were found significantly more often in patients with a gonococcal infection, but the presence of mycoplasmas could not be correlated with symptoms of genital infection or with a leucocytic reaction in the cervical material. Such a reaction was found significantly more often in patients with $N$. gonorrhoeae or $T$. vaginalis. Culturing for $T$. vaginalis is therefore especially recommended in patients with a leucocytic reaction in whom no gonococci or flagellates can be detected by direct microscopical examination of smears. For culture of $T$. vaginalis, cervical specimens taken with charcoal-coated cotton-wool swabs and transported in Stuart's medium gave results comparable with specimens taken from the vaginal secretion and transported in Diamond's medium. 


\section{References}

Aluotto, B. B., Wittler, R. C., Williams, C. O., and FABER, J. E. (1970) Int. F. Syst. Bact., 20, 35

Bartunek, J., and Schultze, M. (1972) Hautartz, 23, 368

Caspi, E., Herczeg, E., Solomon, F., and Sompolinsky, D. (1971) Amer. F. Obstet. Gynec., 111, 1102

- Solomon, F., and Sompolinsky, D. (1972) Israel F. med. Sci., 8, 122

CatTerall, R. D. (1966) Lancet, 2, 830

- (1971) Brit. F. vener. Dis., 47, 45

Chanock, R. M., Hayflick, L., and Barile, M. F. (1962) Proc. nat. Acad. Sci. (Wash.), 48, 41

Clyde, W. A., JR. (1964) F. Immunol., 92, 958

Department of Health and Social Security (1971) 'On the State of the Public Health'. Report of the Chief Medical Officer for 1970, p. 61. H.M.S.O., London

Diamond, L. S. (1957) F. Parasitol., 43, 488

Drake, T. E., and MaIBACH, H. I. (1973) Postgrad. med. f., 53, 83

EdDie, D. A. S. (1968) f. med. Microbiol., 1, 153

Franciosi, R. A., Knostman, J. D., and Zimmerman, R. A. (1973) F. Pediat., 82, 707

Gardner, H. L., and Dukes, C. D. (1955) Amer. F. Obstet. Gynec., 69, 962

Gästrin, B., and Kallings, L. O. (1968) Acta path. microbiol. scand., 74, 362

Gnarpe, H. (1973) Personal communication.

__ and Friberg, J. (1972) Amer. F. Obstet. Gynec., 114, 727

- -, Wallin, J., and Forsgren, A. (1972) Brit. F. vener. Dis., 48, 496

Holmes, K. K., Counts, G. W., and Beaty, H. N. (1971) Ann. intern. Med., 74, 979

McCormack, W. M., Almeida, P. C., Bailey, P. E., Grady, E. M., and LeE, Y.-H. (1972) f. Amer. med. Ass., 221, 1375

—, Braun, P., Lee, Y.-H., Klein, J. O., and Kass, E. H. (1973) New Engl. f. Med., 288, 78

Pariser, H. (1972) Med. Clin. N. Amer., 56, 1127
Porter, P. S., and Lyle, J. S. (1966) Arch. Derm., 93, 402

Robinson, S. C., and Mirchandani, G. (1965) Amer. $\mathcal{F}$. Obstet. Gynec., 91, 1005

Rohatiner, J. J., and Grimble, A. (1970) f. Obstet. Gynec. Brit. Cwlth, 77, 1013

Shepard, M. C., and LunCEFord, C. D. (1970) Appl. Microbiol., 20, 539

Sompolinsky, D., Solomon, F., Leiba, H., Caspi, E., Lewinsohn, G., and AlmoG, C. (1971) Israel f. med. Sci., 7, 745

Wallin, J. (1974) Acta derm.-venereol. (Stockh.), 54, 157

- and ForsGren, A. (1974) Brit. F. vener. Dis., 50, 148

Willcox, R. R. (1972) Ibid., 48, 163

Yaffee, H. S., and Grots, I. (1965) New Engl. f. Med., 272, 647

\section{Les maladies sexuellement transmises chez la} femme

\section{SOMMAIRE}

La microbiologie cervicale a été étudiée ${ }^{-c h e z} 341$ nouvelles consultantes consécutives dans une clinique vénéréologique. Les résultats montrent que la plupart des bactéries n'ont pas de signification en ce qui regarde l'existence d'une sécrétion vaginale ou l'augmentation du nombre des leucocytes dans les prélèvements cervicaux. Des mycoplasmes furent trouvés significativement plus souvent chez les sujets atteints de gonococcie, mais la présence de mycoplasmes fut sans rapport avec les symptômes d'infection génitale ou avec une réaction leucocytaire dans les prélèvement cervical. Une telle réaction a été trouvée significativement plus fréquente chez les malades atteintes d'infection à $N$. gonorrhoeae ou à $T$. vaginalis. La culture pour $T$. vaginalis est donc spécialement recommandée chez les malades présentant une réaction leucocytaire et chez lesquelles l'examen microscopique des sécrétions ne montre ni gonocoques ni flagellés. Pour la culture de $T$. vaginalis, les spécimens cervicaux pris avec un écouvillon de coton charbonné et transporté en milieu de Stuart ont donné des résultats comparables à ceux des spécimens de sécrétions vaginales transportés en milieu de Diamond. 